\title{
Immunohistological evidence for a chronic intramyocardial inflammatory process in dilated cardiomyopathy
}

\author{
U Kühl, M Noutsias, B Seeberg, H-P Schultheiss
}

\begin{abstract}
Objective-To determine whether immunohistochemical analysis of cardiac biopsies from patients presenting clinically as dilated cardiomyopathy (DCM) show a chronic inflammatory process.

Design-Comparative case control study. Setting-Tertiary referral centre. Patients-Biopsies from 170 patients with DCM and 85 control patients with other cardiac diseases.

Results-Nine patients had sufficient interstitial inflammatory cells to be called borderline myocarditis on conventional histology, leaving 161 patients with DCM. In 78 patients with DCM $(48 \%)$ there were T lymphocytes in the myocardium. In 48 (62\%) of these $78 \mathrm{~T}$ lymphocyte densities were in the range $2-14$ per high power field (HPF), equivalent to 7-50 per $\mathbf{m m}^{2}$ of tissue. In $43(89 \%)$ interstitial and endothelial immune activation was demonstrated by MHC expression. In 30 patients with $T$ cell counts in the range 1.5-2.0 per HPF, $80 \%$ also showed endothelial activation. Lymphocyte density correlated with increased expression of MHC class I and II antigens and the adhesion molecules ICAM, VCAM, ELAM, LFA-3, and GMP140. In all control biopsies the $T$ lymphocyte density was less than 1.0 per HPF (less than 2-5 per $\mathbf{m m}^{2}$ of tissue).

Conclusions-Nearly half the patients with DCM had increased T lymphocyte density and immune activation of endothelial and interstitial cells in their cardiac biopsies. A chronic autoimmune process is still active within the myocardium in a significant percentage of patients with DCM. Immunohistochemical analysis of cardiac biopsies will enhance the sensitivity of cardiac biopsy and is essential for the diagnosis of myocarditis.
\end{abstract}

(Heart 1996;75:295-300)

Keywords: acute myocarditis; dilated cardiomyopathy; $T$ cells numbers; immune activation

Dilated cardiomyopathy (DCM) is a disease of unknown aetiology. ${ }^{12}$ Experimental and clinical data, however, suggest a causal relation between myocarditis and dilated cardiomyopathy. ${ }^{34}$ In both diseases, increased autoantibody titres to several cardiac autoantigens have been described. ${ }^{5-10}$ Persistence of viral RNA has been demonstrated in endomyocardial biopsy specimens from some patients. ${ }^{11} 12$

One proposed pathogenetic mechanism for DCM is that acute viral myocarditis develops into a chronic autoimmunological process directed against cryptic myocardial epitopes or viral neo-antigens in genetically predisposed patients. ${ }^{1314}$

About $90 \%$ of adults with acute viral myocarditis recover completely. A few slowly progress to cardiac dysfunction. In patients admitted to hospital with chronic heart failure dating back at least several months or even years light microscopy of endomyocardial biopsies often shows only non-specific fibrosis and these cases are categorised as DCM. The diagnosis of a chronic inflammatory process is, however, difficult to establish by light microscopy. Cellular infiltrates are often sparse and may be missed by sampling error. ${ }^{1516}$ In sections stained with haematoxylin and eosin it is not possible to distinguish unequivocally between non-inflammatory cells (for example, fibroblasts or pericytes) and infiltrating lymphocytes. ${ }^{17} 18$

Immunohistological techniques have now been successfully introduced to identify more accurately cellular infiltrates in myocardial biopsies and this study determines the frequency of increased lymphocytic infiltrates in DCM detected by these more specific techniques. The expression patterns of additional antigens which are expressed during an active immunological process within the myocardium (for example, HLA classes I and HLA-DR antigens, or adhesion molecules) were also analysed.

\section{Patients and methods \\ PATIENTS}

We studied 170 patients with dilated cardiomyopathy (116 men, 54 women, mean (SD) age $50 \cdot 1(14 \cdot 3)$ years). They had had symptoms for more than six months (6 months-10 years) without any clinical history of prior viral infection. All patients underwent cross sectional echocardiography and electrocardiography. All patients had left heart catheterisation for ventriculography, selective coronary angiography, and assessment of left and right ventricular haemodynamic function. The mean (SD) ejection fraction (EF) was $44 \cdot 7(18.4) \%$ (range $15 \%-75 \%$ ), the end diastolic volume index (EDVI) was $140(56) \mathrm{ml}$ $\times \mathrm{m}^{2}$, and the left ventricular end diastolic pressure (LVEDP) was $16 \cdot 3(9 \cdot 1) \mathrm{mm} \mathrm{Hg}$. 
Right ventricular biopsies were obtained from the interventricular septum from all patients.

As controls we also obtained heart tissue from 85 patients without clinical indication of inflammatory heart disease. These included patients with ischaemic heart disease $(n=20)$, hypertension $(n=20)$, valvar heart disease ( $n$ $=10)$, and hypertrophic cardiomyopathy ( $\mathrm{n}=$ 35).

\section{SAMPLE PREPARATION}

For histology two biopsies were fixed in formalin. For immunohistology five biopsy specimens were snap frozen in a slurry of dry ice and methylbutane at $-70^{\circ} \mathrm{C}$. One biopsy specimen was serially cut into sections that were $5 \mu \mathrm{m}$ thick; for immunohistological evaluation 6-9 serial sections were analysed from this first biopsy for each antibody (see below). Biopsies were examined blindly by two independent observers.

\section{ANTIBODIES}

Mononuclear infiltrates were identified by their reaction with T200 (CD45RA antibodies) (Dako; Hamburg). For lymphocyte staining, anti-CD2-/LFA-2 and CD3-antibodies were purchased from Dakopatts ( $T$ lymphocytes). Subtyping of $\mathrm{T}$ helper/inducer or cytotoxic/ suppressor lymphocytes was performed with anti-CD4 and anti-CD8 antibodies from Coulter, Florida. To evaluate activated cells, serial sections were also stained with the cell activation markers UCHL-1 (CD45RO, T memory cells) (Dakopatts), anti-HLA class I and II antibodies (Dakopatts). Antibodies for adhesion molecules (immunoglobulin superfamily-CD54/ICAM-1, VCAM-1, CD58/ LFA-3-and $\beta_{2}$-leucocyte-integrins-CD18/ CD11- $\beta$-chain, CD11a/LFA-1, CD11b/Mac1) and for activated macrophages $-27 \mathrm{E} 10$, RM 3/1, 25 F 9-were obtained from Dianova (Hamburg, Germany).

\section{IMMUNOHISTOLOGICAL STAINING}

Cryotome sections ( $5 \mu \mathrm{m})$ were preincubated with fetal calf serum (FCS) to saturate nonspecific immunoglobulin binding sites. Specific monoclonal mouse anti-human antibodies in pretested dilutions were then incubated with the sections for 45 minutes at room temperature in a humidified chamber. Unbound antibodies were removed by three washes with phosphate buffered saline, each lasting three minutes. Peroxidase labelled rabbit-anti-mouse immunoglobulin (Dianova), diluted at $1: 200$ in phosphate buffered saline containing $10 \%$ FCS (30 minutes, room temperature) was used to detect specifically bound primary antibodies. Staining was performed with 3-amino-9-ethylcarbazole as a chromogene against a haematoxylin counterstain. Sections were coverslipped with Kaiser's gelatin (E Merck, Darmstadt, Germany).

\section{LIGHT MICROSCOPIC EVALUATION}

Acute myocarditis was diagnosed histologically if light microscopy showed infiltrating interstitial mononuclear cells (leucocytes, lymphocytes, or macrophages) associated with myocardial injury according to the Dallas Criteria. ${ }^{1920}$ The diagnosis of borderline myocarditis required the presence of infiltrating lymphocytes with or without interstitial or reparative fibrosis but with no cell necrosis.

\section{IMMUNOHISTOLOGICAL EVALUATION OF BIOPSIES}

For immunohistological evaluation, the number of immunoreactive $\mathrm{T}$ lymphocytes (CD2, $\mathrm{CD} 3, \mathrm{CD} 4$, or CD8) were counted in one entire specimen. Cell numbers were expressed as the mean value of at least 10 counted high power fields (HPF, $\times 400)$ each being equivalent to $0.28 \mathrm{~mm}^{2}$. When the mean number of lymphocytes exceeded 2.0 per HPF $(7 \cdot 0$ per $\mathrm{mm}^{2}$ ) the result was regarded as abnormal. Cases where there was focal infiltration with an average single cell number between 1.5 and $2 \cdot 0$ lymphocytes per HPF (5-7 cells per $\mathrm{mm}^{2}$ ) were regarded as positive, provided that the expression of additional immune markers-for example, to the MHC antigens-was also enhanced. These criteria were based on published results ${ }^{21} 22$ and on our control group in which mean lymphocyte counts were $0.7(0.4)$ cells (range $0.0-1.4)$ per HPF $(0.0-5.0$ per $\mathrm{mm}^{2}$ ). Infiltrating activated macrophages were regarded as pathologically increased if cell counts were $>1.5$ cells per HPF (equivalent to 5 cells $/ \mathrm{mm}^{2}$ ). In CD3-negative biopsies from patients with dilated cardiomyopathy and the control group fewer than 1.5 macrophages per $\mathrm{mm}^{2}$ were counted.

\section{EXPRESSION OF MHC CLASS I AND II ANTIGENS} AND ADHESION MOLECULES

In addition to lymphocyte staining, endomyocardial biopsy sections were screened semiquantitatively for relative levels of MHC class I and II antigens and adhesion molecule expression on both the vascular endothelium and interstitial cells.

Immunoperoxidase staining was graded as follows:

Grade $0-1+$ No immunoreactivity or weak staining similar to that seen in negative control samples, with endothelial cells faintly stained; few interstitial cells are marked.

Grade 2+-Enhanced expression on endothelial cells and increased number of positively stained interstitial cells.

Grade $3+-$ Endothelial cells are strongly immunoreactive. There are more positive interstitial cells and the intensity of staining on each cell is increased.

\section{Results}

In routine haematoxylin and eosin stained sections, nine $(5 \%)$ of the 170 biopsy specimens showed an increased number of interstitial cells without myocytolysis. These findings were consistent with the definition of borderline myocarditis. ${ }^{19} 20$

Immunohistological cell marker analysis of frozen sections revealed pathologically increased lymphocytic infiltrates in biopsies from 78 of the patients ( $48 \%$ ) when stained with antibodies directed against $\mathrm{CD} 2, \mathrm{CD} 3$, 
Table 1 Immunohistologically evaluated numbers of infiltrating T-lymphocytes, activated interstitial cells, and percentage of activation of the vascular endothelium in endomyocardial biopsies from 170 patients with the clinical diagnosis of dilated cardiomyopathy (mean cell counts from at least 10 high power fields magnification: $\times 400$ (equivalent to $0.28 \mathrm{~mm}^{2}$ )

\begin{tabular}{|c|c|c|c|c|c|c|c|}
\hline Lymphocytes & $n$ & $C D 2$ & $C D 3$ & $C D 4$ & $C D 8$ & $\begin{array}{l}\text { Activated } \\
\text { interstitial } \\
\text { cells }\end{array}$ & $\begin{array}{l}\text { Activated } \\
\text { vascular } \\
\text { endothelium } \\
(\%)\end{array}$ \\
\hline \multicolumn{8}{|l|}{$>2 \cdot 0$} \\
\hline $\begin{array}{l}\text { cells/HPG }{ }^{\star} \\
1 \cdot 5-2 \cdot 0\end{array}$ & 48 & $3 \cdot 8(2 \cdot 6)$ & $3 \cdot 5(2 \cdot 6)$ & $2 \cdot 0(1 \cdot 8)$ & $1 \cdot 8(1 \cdot 1)$ & $1 \cdot 8(3 \cdot 4)$ & 80 \\
\hline cells/HPF* & 30 & $1 \cdot 7(0.2)$ & $1.7(0.2)$ & $1 \cdot 6(1 \cdot 1)$ & $1 \cdot 2(0 \cdot 2)$ & $1 \cdot 7(2 \cdot 8)$ & 80 \\
\hline cells/HPF ${ }^{\star}$ & 92 & $0.6(0.4)$ & $0.5(0.4)$ & $0.2(0.3)$ & $0.2(0.3)$ & $0.6(1.0)$ & 17 \\
\hline Controls & 85 & $0.8(0.4)$ & $0.7(0.4)$ & $0.4(0.3)$ & $0.4(0.3)$ & $<0.2)$ & 12 \\
\hline
\end{tabular}

^HPF, high power field $(\times 400)$.

CD4, or CD8 antigens (table 1, fig 1). In 48 of the 78 positive samples $(62 \%)$ there was $T$ cell infiltration of between two and 13.8 cells per HPF (equivalent to $7-50$ cells per $\mathrm{mm}^{2}$ ). In 30 biopsy specimens $(38 \%)$ a mild cellular infiltration with $>1.5$ but $<2 \mathrm{~T}$ lymphocytes was present. These low cell numbers were regarded as pathologically increased if additional immune markers such as an enhanced expression of MHC class I or II antigens and/or an increased number of activated infiltrating or endothelial cells could be demonstrated.

In the control tissues and the $\mathrm{CD} 3$ negative biopsies only weak immunoreactivity of few interstitial and endothelial cells was detectable with antibodies to MHC class I and II antigens or adhesion molecules of the $\beta_{1}$-integrin, immunoglobulin, and selectin families (table 2 and fig 2). In biopsy specimens with pathologically increased lymphocytic infiltrates $(>2 \cdot 0$ cells/HPF), however, $91 \%$ of $\mathrm{CD} 3$ positive samples showed enhanced expression of class I or II antigens (class I, 53\%; class II, $87 \cdot 5 \%$ ) (table 2). There was an increase not only in the number of stained interstitial cells but also in the intensity of staining on each cell compared with negative biopsies (fig 2). Staining of MHC antigens was also more intense on the vascular endothelium of immunohistologically positive biopsies (fig 2). Cell adhesion molecules were expressed in most of the CD3positive tissues. CD11a/LFA-1, CD11b/ Mac-1, CD1 1c/p150,95, CD49d.VLA-4, and CD29/VLA- $\beta$-chain of the integrin family were found in $55-89 \%$. Similarly, members of the immunoglobulin (CD54/ICAM-1, VCAM-1, and LFA-3) and selectin families (CD62E/ELAM-1, CD62P/GMP140) were enhanced in $36-88 \%$. One important feature of the increased immunoreactivity of the adhesion molecules and the MHC antigens is that they are spread equally over the entire biopsy specimen regardless of the focal or diffuse type

Table 2 Expression of histocompatibility antigens (MHC class I and II) in endomyocardial biopsies from 170 patients with clinically suspected dilated cardiomyopathy in correlation with the lymphocytic infiltration

\begin{tabular}{llrll}
\hline $\begin{array}{l}\text { Immunohistological } \\
\text { findings (CD3 staining) }\end{array}$ & $n$ & $\begin{array}{l}I / I I \\
(\%)\end{array}$ & $\begin{array}{l}I \\
(\%)\end{array}$ & $\begin{array}{l}I I \\
(\%)\end{array}$ \\
\hline Severe infiltration & 48 & 91 & 53 & $87 \cdot 5$ \\
Mild infiltration & 30 & 100 & 67 & 67 \\
No infiltrates & 92 & 31 & 6 & 26 \\
Control & 85 & 19 & 6 & 16 \\
\hline
\end{tabular}
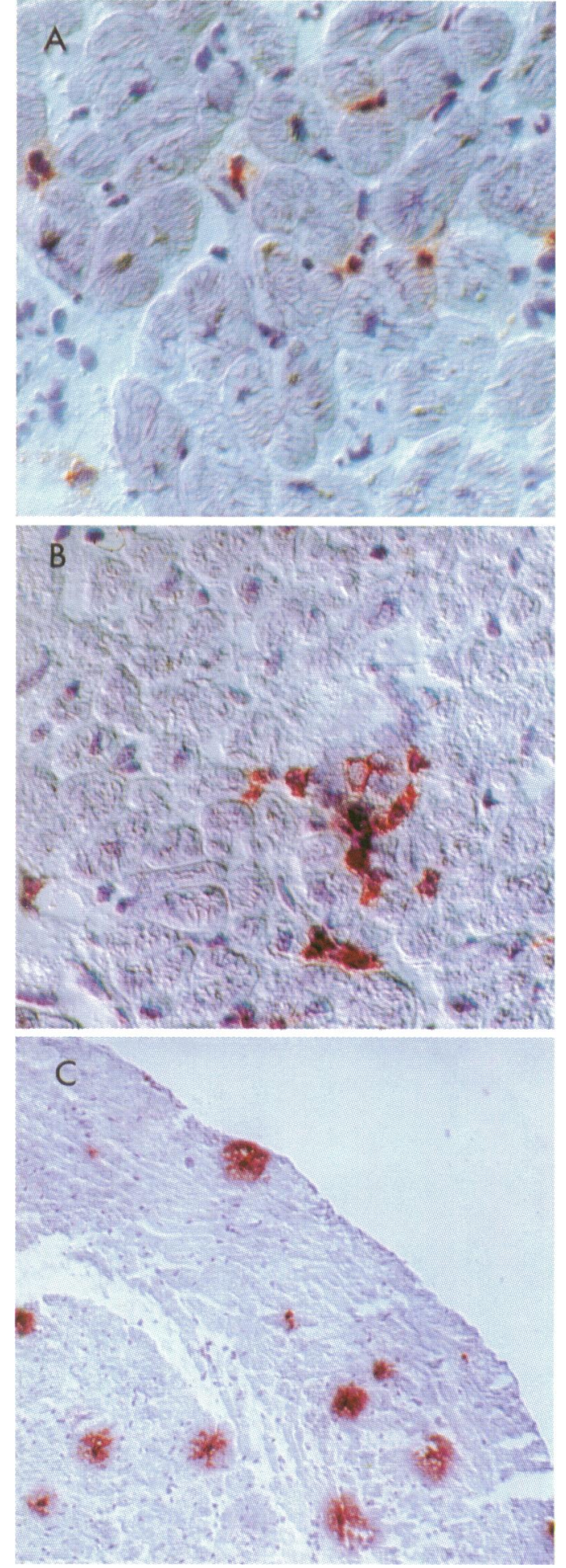

Figure 1 Immunohistological staining of cardiac tissue. $C D 3$ positive $T$ lymphocytes present in diffuse $(A)$ or focal distribution (B). (C) Activated macrophages. Original magnification $A-C \times 400$.

of distribution of the lymphocytic infiltration (fig 2). None of the control tissues analysed showed a significant degree of lymphocytic infiltration or enhanced expression of the additional immune markers. In all samples from patients with coronary artery disease, hypertension, or in the material we obtained after valve replacement, less than $1.0 \mathrm{CD} 3$-positive lymphocytes per HPF ( 3.5 per $\left.\mathrm{mm}^{2}\right)$ were detected (table 1). These cell numbers were similar to those found in the remaining 92 negative biopsy specimen $(0.5(0.4))$ of 
Figure 2 HLA class II antigen expression. (A) Distribution of $H L A-D R$ in normal cardiac tissue. In biopsies with increased Tlymphocytic infiltration immunoperoxidase staining on interstitial cells and the vascular endothelium was markedly enhanced

(B) and found within the entire biopsy specimen

(C). Magnification $A, B$

$\times 400 ; C \times 40$



patients with clinically suspected dilated cardiomyopathy (table 1).

Activated macrophages (mean value $>1.5$ cells/HPF, $>5$ cells $/ \mathrm{mm}^{2}$ ) were detected in
$80 \%$ of $\mathrm{CD} 3$ positive biopsies (fig 2). Macrophages of the acute stage of activation were present in $75 \%$. Cells in the intermediate stage of activation were found in $41 \%$ of biopsies while late stage activated cells were present in $50 \%$ (table 3).

Analysis of CD45RA positive leucocytes (T200) showed a maximum of six cells per HPF (21.5 cells per $\left.\mathrm{mm}^{2}\right)$ in biopsies regarded as negative for a chronic inflammatory process because lymphocyte counts were below 1.5 cells per HPF and no enhanced immunoreactivity for HLA-antigens or adhesion molecules could be detected. In CD3 positive biopsy specimens with enhanced HLA expression the number of cells stained with the panleucocyte marker T200 ranged from 1.5 to 14 cells per HPF (5-50 cells per $\mathrm{mm}^{2}$ ). However, in $69 \%$ of analysed biopsies (54 out of 78) the mean value of T200-reactive cells was below the upper limit of six cells per HPF found in negative biopsies (table 1). Therefore, T200 immunoreactivity does not correlate with the enhanced expression of the other immune markers which demonstrate an activated reactivity of the myocardium. Results obtained using the pan-T marker (T200, CD45RA) are not reliable for the diagnosis of an inflammatory myocardial process.

\section{Discussion}

Acute myocarditis is a possible precursor of dilated cardiomyopathy. ${ }^{12}$ The histological diagnosis of myocarditis depends on the detection of infiltrating lymphocytes. It is, however, difficult to distinguish between lymphocytes and other interstitial cells.

The characteristics of acute myocarditis according to the Dallas Criteria, ${ }^{19}{ }^{20}$ such as myocytolysis adjacent to lymphocytic infiltrates, are not likely to be found in patients with clinically suspected dilated cardiomyopathy whose onset of symptoms dates back months or even years. In various studies the reported incidence of "myocarditis" in patients with clinical dilated cardiomyopathy ranged from zero to $67 \% .{ }^{16}$ This unacceptable disparity is largely the result of the difficulty of establishing an unequivocal histological diagnosis for myocarditis by light microscopy.

The question that arises is "what density of cellular infiltration indicates a significant myocarditis?" Different groups have quantified the infiltrating cells by histological and immunohistological methods in the context of acute myocarditis. Edwards and colleagues ${ }^{23}$ suggested that finding more than five lymphocytes per HPF $(\times 400)$ in sections stained

Table 3 Percentage of activated macrophages showing acute, intermediate, and late stage of inflammation and HLA expression in biopsies with or without increased mononuclear infiltrates

\begin{tabular}{lllllll}
\hline & \multicolumn{5}{l}{ Stage of inflammation of macrophages } \\
\cline { 5 - 7 } Immunohistology & $n$ & $\begin{array}{l}\text { Activated } \\
\text { macrophages }\end{array}$ & $\begin{array}{l}\text { Acute } \\
\text { inflammation }\end{array}$ & $\begin{array}{l}\text { Intermediate } \\
\text { inflammation }\end{array}$ & $\begin{array}{l}\text { Late } \\
\text { inflammation }\end{array}$ & $\begin{array}{l}\text { Enhanced } \\
\text { HLA/IIII } \\
\text { expression }\end{array}$ \\
\hline Positive & 78 & $\begin{array}{l}80 \% \\
(\mathrm{n}=62)\end{array}$ & $75 \%$ & $41 \%$ & $50 \%$ & $93 \%$ \\
Negative & 92 & $75 \%$ & $50 \%$ & $50 \%$ & $50 \%$ \\
\hline
\end{tabular}


with haematoxylin-eosin is a reliable indicator of myocarditis. A lower limit of five lymphocytes for the diagnosis of acute myocarditis if cells were associated with myocardial injury has been accepted. None the less, when immunohistochemical techniques are used $<20 \%$ of infiltrating cells are $\mathrm{T}$ lymphocytes. ${ }^{22}$ Similar limitations were reported by Linder and coworkers, ${ }^{21}$ who suggested an upper limit for normal controls of 25-30 interstitial inflammatory cells per $\mathrm{mm}^{2}$ when counts were made on slides stained with haematoxylin and eosin, whereas immunohistochemical methods showed only $3 \cdot 6$ lymphocytes $/ \mathrm{mm}^{2}$.

These studies did not concentrate on patients with clinical DCM or normal hearts. In these studies which showed an upper limit of five lymphocytes per HPF in normal myocardium few patients with dilated cardiomyopathy were examined both histologically and immunohistologically. In contrast to these reports, Steenbergen et al and Mues et al using immunohistological methods showed $<1$ lymphocyte per HPF in normal myocardium. ${ }^{24} 25$

This figure of $<1 \mathrm{~T}$ cell per HPF in the non-inflamed myocardium is confirmed by our results which show a mean of $0.8(0.4)$ lymphocytes per HPF $\left(1 \cdot 5-4 \cdot 0\right.$ cells per $\left.\mathrm{mm}^{2}\right)$ in non-inflamed cardiac tissue $(\mathrm{n}=85)$ and in $54 \%(n=92)$ of biopsies from patients with clinically suspected dilated cardiomyopathy showing no further immunohistological signs of inflammation. The results accord with the low numbers of activated lymphocytes $(<5 \%)$ or macrophages $(7 \%)$ in the interstitium and the weak immunoreactivity of HLA antigens or adhesion antigens in these biopsies.

Our data clearly show that many patients with dilated cardiomyopathy have an increased number of myocardial $\mathrm{T}$ lymphocytes. Thus some cases of dilated cardiomyopathy could be designated as chronic myocarditis. But does the increased lymphocytic infiltration indicate that an active immunological process is responsible for the progressive impairment of ventricular function in dilated cardiomyopathy? Unlike histological staining, immunohistological analysis allows us to study activation of infiltrating cells and their interaction with an activated vascular endothelium.

The enhanced expression of MHC antigens and cell adhesion molecules is mandatory for the activation and regulation of the immunological process. ${ }^{26}$ As shown above, an enhanced expression of human histocompatibility antigens and further adhesion molecules on interstitial cells or vascular endothelium or both were detected in nearly all of the 78 CD3-positive biopsies (fig 2) but these features were absent or showed only faint immunoreactivity in lymphocyte negative cardiac tissues from patients with dilated cardiomyopathy. 2829 The expression of these molecules was spread equally over the entire biopsy specimen whether distribution of the infiltrates was diffuse or focal. This indicates a generalised active immunological process affecting the entire myocardium.
The prognostic value of detecting $\mathrm{T}$ lymphocytes and activated macrophages and endothelial cells in dilated cardiomyopathy is controversial. Macrophages may be of great importance for the induction and progression of the smouldering inflammatory process caused when local release of cytokine activates the vascular endothelium and they are a prerequisite for the induction of adhesion molecules. ${ }^{262730}$ The activated vascular endothelium provides co-stimulatory signals to activated circulating $T$ cells which mediate adhesion of stimulated leucocytes and their consecutive transendothelial migration into inflamed tissues. ${ }^{31} 32$

Pathologically increased activated lymphocytic infiltrates in association with an enhanced expression of adhesion molecules can be regarded as a clear cut indication of a persisting chronic inflammatory process.

Patients with a positive immunohistological result represent a subgroup of so-called dilated cardiomyopathy which is characterised by a chronic ongoing myocarditis. In the future these immunohistochemical methods may be the basis for the diagnosis, the prediction of clinical outcome, and the clinical management of patients with clinically suspected dilated cardiomyopathy. Preliminary results of immune suppression of patients characterised immunohistologically as having chronic immune activation in the myocardium confirm this assumption. ${ }^{33}$

1 World Health Organization. Cardiomyopathies. In: Report of a WHO Committee, Geneva, 1984:1-64.

2 Abelmann WH, Lorell BH. The challenge of cardiomyopathy. F Am Coll Cardiol 1989;13:1219-39.

3 Zee-Cheng CS, Tsai CC, Palmer DC, Codd JE, Pennington DG, Williams GA. High incidence of myocarditis by endomyocardial biopsy in patients with idiopathic congestive cardiomyopathy. $\mathcal{f} \mathrm{Am}$ Coll Cardiol 1984;3:63-70.

4 MacArthur CGC, Tarin D, Goodwin JF, Hallidie-Smith KA. The relationship of myocarditis to dilated cardiomyopathy. Eur Heart f 1984;5:1023-35.

5 Schulze $K$, Becker BF, Schauer R, Schultheiss H-P. Antibodies to the ADP/ATP carrier-an autoantigen in myocarditis and dilated cardiomyopathy-impair cardiac function. Circulation 1990;81:959-69.

6 Schultheiss H-P, Schulze K, Schauer R, Witzenbichler B, Strauer BE. Antibody-mediated imbalance of myocardial Strauer BE. Antibody-mediated imbalance

7 Schultheiss H-P, Ulrich G, Janda I, Kühl U, Morad M. Antibody-mediated enhancement of calcium permeability in cardiac myocytes. $\mathcal{E}$ Exp Med 1988;168:2105-19.

8 Limas CJ, Goldenberg JF, Limas C. Autoantibodies against $\beta$-adrenoceptors in human idiopathic dilated cardiomyopathy. Circ Res 1989;64:97-103.

9 Neu N, Beisel KW, Traysman MD, Rose NR, Craig SW. Autoantibodies specific for cardiac myosin isoform are found in mice susceptible to Coxsackie B3-induced myocarditis. F Immunol 1987;138:2488-92.

10 Wolff P, Kühl U, Schultheiss H-P. Laminin distribution and autoantibodies to laiminin in dilated cardiomyopathy and myocarditis. Am Heart $\mathcal{F}$ 1989;117:1303-9.

11 Bowles NE, Olsen EGJ, Richardson PJ, Archard LC. Detection of Coxsackie B-virus-specific RNA sequences in myocardial biopsy samples from patients with in myocardial biopsy samples from patients with $1120-2$.

12 Kandolf A, Kirschner P, Ameis D, Canu A, Erdmann E, Schultheiss H-P, et al. Enteroviral heart disease: diagnosed by in-situ hybridisation. In: New concepts of viral nosed by in-situ hybridisation. In: New concepts of viral
heart disease, ed Schultheiss H-P. Berlin: SpringerVerlag, 1988:337-48.

13 Dilated cardiomyopathy and enteroviruses. Lancet 1990; 336:971-73.

14 Schwimmbeck PL, Bland NK, Schultheiss H-P. The possible value of synthetic peptides in the diagnosis and therapy 1991;12:76-80.

15 Hauck AJ, Kearney DL, Edwards WD. Evaluation of postmortem endomyocardial biopsy specimen from 38 patients with lymphocytic myocarditis: Implication for role of sampling error. Mayo Clin Proc 1989;64:1235-45. 16 Shanes JG, Ghali J, Billingham ME, Ferrans VJ, Fenoglio 
JJ, Edwards WD, et al. Interobserver variability in the pathologic interpretation of endomyocardial biopsy pesults Circulation 1987;75:401-5.

17 Fenoglio J, Ursell PC, Kellogg CF, Drusin RE, Weiss MB. Diagnosis and classification of myocarditis by endomy ocardial biopsy. $N$ Engl $₹$ Med 1983;308:12-8.

18 Dec GW Jr, Palacios IF, Fallon JT, Aretz HT, Mills J, Mill DC-S, et al. Active myocarditis in the spectrum of acute dilated cardiomyopathies. $N$ Engl $f$ Med 1985;312: 885-90.

19 Aretz HT, Billingham ME, Edwards WD, Factor S, Fallon $\mathrm{JT}$, Fenoglio JJ Jr, et al. Myocarditis, a histopathologic definition and classification. F Cardiovasc Pathol 1986;1: 3-14.

20 Aretz HT. Myocarditis, the Dallas Criteria. Hum Pathol 1987;18:619-24.

21 Linder J, Cassling RS, Rogler WC, Wilson JE, Markin RS, Sears TD, et al. Immunohistological characterization of Sears TD, et al. Immunohistological characterization of lymphocytes in uninflamed ventricular

22 Milei J, Bortman G, Fernandez-Alonso G, Grancelli $H$ Beigelman R. Immunochemical staining of lymphocyte for the reliable diagnosis of myocarditis in endomyocar dial biopsies. Cardiology 1990;77:77-85.

23 Edwards WD, Holmes DR, Reeder GS. Diagnosis of active lymphocytic myocarditis by endomyocardial biopsy. Quantitative criteria for light microscopy. Mayo Clin Pro 1982;57:419-25.

24 Steenbergen C, Kolbeck PC, Wolfe JA, Anthony RM, Sanfilippo FP, Jennings RB. Detection of lymphocytes in endomyocardium using immunohistochemical tech- niques. Relevance to evaluation of endomyocardial biopniques. Relevance to evaluation of endomyocardial biop-
sies in suspected cases of lymphocytic myocarditis. $\mathcal{F} A p p l$
Cardiol $1986 ; 1: 63-73$.

25 Mues B, Brisse B, Zwado G, Themann H, Bender F, Sorg C. Phenotyping of macrophages with monoclonal antibodies in endomyocardial biopsies as a new approach to diagnosis of myocarditis. Eur Heart f 1990;11:619-27.

26 Kühl U, Noutsias M, Seeberg B, Schannwell M, Welp LB Schultheiss H-P. Chronic inflammation in the myocardium of patients with clinically suspected dilated cardiomyopathy. $\mathcal{F}$ Cardiac Failure 1994;1:13-25.

27 Kühl U, Noutsias M, Seeberg B, Schannwell M, Welp LB, Schultheiss H-P. F Cardiac Failure 1994;1:231-45.

28 Daar AS, Fuggle SV, Fabre JW, Ting A, Morris PJ. The detailed distribution of $\mathrm{HL} A-A, B, C$ antigens in normal human organs. Transplantation 1984;38:287-92.

29 Natali PG, De Martino C, Quantara V, Nicotra MR Frezza F, Pellegrino MA, et al. Expression of Ia-like antigens in normal human nonlymphoid tissues. antigens in normal huma

30 Kühl U, Noutsias M, Schultheiss H-P. Immunohistochemistry in dilated cardiomyopathy. Eur $\mathcal{F}$ Cardiol 1995;

31 Springer TA. Adhesion receptors of the immune system. Nature 1990;346:425-34.

32 Bober JS, Collins T, Gimbrone MA, Libby P, Reiss CS Inducible expression of class II major histocompatibility complex antigens and the immunogenicity of vascula endothelium. Transplantation 1986;41:141-6.

33 Kühl U, Schultheiss H-P, Strauer BE. Methylprednisolone in chronic myocarditis. Postgrad Med F 1994;70:S35-S42. 